\title{
Participation of Nonprofit Service Organizations in the Processes That Provide for Sustainable and Safe Development of the Territories
}

\author{
Elena Dvoryadkina*, Alexandra Eliseeva, Dina Prostova \\ Ural State University of Economics, Ekaterinburg, Russia \\ ${ }^{*}$ Corresponding author. Email: elena.dvoryadkina@yandex.ru
}

\begin{abstract}
In view of the significant social role of third sector organizations in the territories' development, the solution of the problems they face in the search and development of a strategy for their sustainable development is a priority task facing the leadership of organizations, as well as leaders and officials at the local (regional) level, the authors consider it necessary to consider the work of socially oriented non-profit organizations in this direction. Thanks to their mobility and coordinated actions of socially-oriented non-profit organizations more quickly than the state helps in solving urgent problems. The authors in their study pay attention to the increase in funding of non-profit organizations for environmental protection, which are conducted in accordance with the approved program of national projects through grant support from state funds.
\end{abstract}

Keywords: Regional economics, non-profit organizations, sustainable development, environmental protection.

\section{NON-PROFIT ORGANIZATIONS AS FULL-FLEDGED SUBJECTS OF ECONOMIC ACTIVITY}

Social and economic development of the country and its regions on the socio-economic path, ensuring the necessary rates of economic growth is not possible without the establishment of the "third sector of the economy", which includes non-profit organizations, and its close interaction with the commercial, private and public sectors in the country and region. Non-profit organizations, as full-fledged subjects of economic activity, become a real economic factor influencing the creation of gross added value in the economic space of the region, and, accordingly, economic growth [11], and, accordingly, affects the sustainable development of regions.

Federal Law No. 7-FZ of 12.01.1996 "On NonProfit Organizations" gives a clear definition of "nonprofit organization", it implies an organization that has no profit as the main goal of its activity and does not distribute its profits between its members.

Non-profit organizations may be established to achieve social, charitable, cultural, educational, scientific and managerial goals, to protect the health of citizens, develop physical culture and sports, meet the spiritual and other non-material needs of citizens, protect the rights and lawful interests of citizens and organizations, resolve disputes and conflicts, provide legal assistance, and for other purposes aimed at achieving public benefit [1].

\section{THEORETICAL BACKGROUND FOR THE RESEARCH OF NONPROFIT ORGANIZATIONS}

The theoretical basis of the research is the theory of social market economy (A. Muller-Armak, W. Oiken, A. Rüstov, W. Röpke, F. A. von Hayek, V. S. Avtonomov, S. A. Bartenev, I. N. Buzdalov, V. P. Gutnik, B. E. Zaritsky, V. N. Kostyuk, Y. V. Latov, S. I. Nevsky, R. M. Nureev, A. G. Khudokormov, A. Chepurenko, etc.), the theory of socio-economics of the region (F. M. Borodkin, V. V. Radaev, V. A. Surin, M. A. Shabanova, A. A. Shulus, E. G. Animitsa, V. A. Sukhikh, etc.), the regional management paradigm (A. S. Marshalova, I. S. Mezhov, A. S. Novoselov, A. K. Osipov, O. M. Roy, A. A. Stepanov, etc.). The author's concept is based on the synthesis of the main provisions of these theories and the justification, on this basis, the value of socially-oriented non-profit organizations as an attribute of sustainable and safe development of territories. 
The methodological basis for the study was the general scientific methods of synthesis, comparative analysis, the method of analogy, as well as a systematic analysis of the provision of grants to nonprofit organizations of state support. The main sources of information were the materials of the official websites of the governing bodies, legislative acts and normative legal documents of the authorities of the Russian Federation, the subjects of the Russian Federation, as well as other materials of the regional governing bodies.

\section{ENVIRONMENTAL ASPECTS OF SUSTAINABLE DEVELOPMENT IN THE SVERDLOVSK REGION}

Sustainable development is development that meets the needs of the present [2].

Perspectives and approaches that put territories at the center of development have once again become important in international debates and policies to implement the 2030 Agenda for Sustainable Development. Among the reasons for the renewed focus are the need for more effective sectoral approaches, localization of sustainable development, better addressing the many and complex challenges facing communities around the world today, and action for inclusive and equitable development.

\subsection{Territorial Approaches as a Model for Localization of Sustainable Development Goals}

Summarizing Territorial Approaches is an attempt by a number of partner organizations to examine the conceptual and evidentiary basis for territorial perspectives, strategies, policies, and programs.

Territorial approaches encompass a wide range of shared, multisectoral development models. These different approaches place different emphasis on governmental and nongovernmental processes, social sustainability and environmental sustainability, local and national efforts, and use different entry points that drive collaborative action. Territorial approaches provide a framework for multi-sector and multistakeholder analysis and action, while recognizing the often complex processes of economic, environmental, and social transformation in a given geographic area. Territorial approaches offer a valuable model for localizing the Sustainable Development Goals (SDGs) and the 2030 Agenda targets demonstrate that territorial approaches are most effective when thematic or institutional entry points suitable for initial collaboration are developed through intersectoral and interdisciplinary coordination. The purpose of such coordination is to link national, international planning and policy activities to people and their needs at territorial levels. At the territorial level, problems most often combine points of entry that are the focus of various ministries, departments, or agencies. From case studies and experience with territorial approaches, scholars identify seven different categories of entry points.

These entry points are:

- $\quad$ local economic development;

- integrated landscape and natural resource management

- $\quad$ natural resource management;

- $\quad$ improved food and nutrition systems;

- $\quad$ inclusive access to public and private services.

The pursuit of sustainable development requires us to address common problems and contradictions and to realize new horizons. Economic growth and wealth creation have reduced global poverty, but vulnerability, inequality, exclusion, and violence have increased within and among societies around the world.

Unsustainable patterns of economic production and consumption contribute to global warming, environmental degradation and an increase in natural disasters, and consequently to the health of the population, which is a direct participant in the reproductive process. To solve these problems, socially oriented non-profit organizations are involved. Nonprofit organizations, as a provider of social services to the population, differ from government and commercial organizations in their ability to respond as quickly as possible to the needs of citizens at minimal cost to effectively address their social problems [4]. It should be noted that a comprehensive empirical review of the global environmental NPO sector is lacking. Most existing studies are characterized by broad generalizations [5-7], single cases or small comparative studies [8-10].

\subsection{State Support of Environmental Non-Profit Organizations in the Sverdlovsk Region}

It is important to note that SONPOs involved in environmental policy are not limited to "green stick," such world-famous names as WWF and Greenpeace. Conservation organizations first emerged in the midnineteenth century and were formed in response to real or perceived threats to wildlife, landscapes, and/or places of special ecological or recreational value. Environmental socially oriented non-profit organizations play a fundamental role in a country with so many natural resources, as well as helping the state, whose efforts to keep these riches in check are limited.

According to the results of the competition of the Presidential Grants Fund in 2018, Sverdlovsk region SONPOs received $204,621,068$ rubles to finance their activities, including 3,273,937 rubles for environmental protection and animal protection. 
In 2019, 130 socially-oriented non-profit environmental and animal protection organizations were registered [3]. According to the Sverdlovsk Region Fund of Presidential Grants, a total of 229,440,534 rubles was allocated for environmental protection and animal welfare, including 2,713,000 rubles for environmental protection.

In 2020, the Sverdlovsk region was allocated 290,845,313 rubles from the Presidential Grants Fund for the implementation of projects. According to the results of the first and second competitions, as well as a special competition (devoted to the implementation of measures to combat the effects of the Covid-19) in the fund of presidential grants in the field of "Environmental Protection and Animal Welfare" 28 projects were submitted, including eight (28.6\%) supported for a total amount of 13,662,680 rubles.

At the end of 2020, the following projects were supported:

- Project of the Autonomous Nonprofit Organization "Podorozhnik. Cultural and Tourist Initiatives" is an Ecological and Tourist Project "The Valley of Snapps". The grant is amounted RUB 499,432. The short-term this project' aim is to launch the project on the territory of Bazhukovo village (adjacent to the Nature Park "Deer Creek") of Nizhneserginsky district of Sverdlovsk region. Recognition of ecotourist brand "Valley of the Shchelpov" in the Sverdlovsk and other regions of the Ural Federal District. The long-term goals of the project include the involvement of computer technology and the Internet space. The brand will be recognizable in Russia and in the world. The information will be available in English and Chinese. It will create movie about new ecological hero Cheek. New purposes will arise as the project develops.

- A project of the Local Public Organization "Pervouralsk City Society for the Protection of Animals" is Veterinary Assistance without Borders. The grant is 3,672,622 rubles. This social project is aimed at popularizing responsible, careful, humane attitude to animals. The project involves the purchase and equipping of a blockmodular portable building where scheduled surgeries, vaccinations and any veterinary services for the shelter pets will be conducted, and also the reception of animals for low-income city residents on a free (and later on a preferential) basis will be organized.

- Project of the Foundation "Pets Rehabilitation Center" is Second Life. The size of the grant is $1,348,172$ rubles. The project is implemented in the territory of Degtyarsk municipal district, Sverdlovsk region, and its duration is 12 months and is devoted to the protection of animals. The main directions of the project are: reduction of the number of homeless animals in the settlements, by mass sterilization, protection of animals, as well as the prevention of cruel treatment of animals.

- The project of the Forest Heritage Foundation is DubFest. The size of the allocated grant is 2,041,016 rubles. The social project "DubFest Festival" is an opportunity to combine the planting of oak seedlings and to attract the general public to environmental activities. Thanks to the festival organizers do not only expect to restore oak forests, but also to informally talk about the importance and conservation of the native region. "Festival" consists of a series of holidays with master-classes for children on the theme "Forest" (master-class "Handicrafts made of natural materials", masterclass "Painting eco-bags"), activist part (competition of thematic "forest" drawings), educational part (lecture - workshop for elder audience), planting oak seedlings.

- The project of the Chusovaya River Heritage Association is the Ural Trail Keepers. RUR 499,013 were allocated for the implementation of this project. The project "Ural Trails Keepers" continues the three-year work of the Association for the preservation of historical, cultural and natural heritage of the territories along the Chusovaya River. The project is aimed at strengthening the tourist attractiveness of small settlements through the construction of eco-trails and the development of new tourist routes by volunteers from among local residents and all concerned citizens of the Sverdlovsk region.

- A project of the "Kind Deed" Charitable Foundation is called as Lessons of Kindness. Friendship has no breed. The grant is amounted RUB 1,965,719. The main idea of the project "Lessons of Kindness. Friendship has no breed" is to teach children kindness by the example of caring for our little brothers. The goals of this project are to popularize kindness and mercy by holding events for pre-school and school children aimed at developing a sense of mercy, to form skills and abilities to care for the weak and defenseless on the example of homeless animals from city shelters and cat cafes; to attract public attention to the problem of homeless animals in the Sverdlovsk region and the Russian Federation; to create a set of training materials in electronic, video and audio format for conducting Lessons of Kindness in kindergartens, schools and etc.

- The Affordable Water project of the Pervouralsk21 Century Community Charitable Foundation. The size of the grant was 2,964,396 rubles. The purpose of this project is to reduce the acute shortage of clean drinking water in the city of 
Pervouralsk. The project "Accessible Water" is aimed at increasing interest in springs as alternative sources of water consumption in the city district of Pervouralsk as well as environmental problems of the district in this sphere.

- The project of Pervouralsk local social movement "City of the Firsts" is Clean Chusovaya Russia. The grant was awarded in the amount of RUB 672,310 . The main goal of this project is to clean the Chusovaya River, its coastal areas and tourist sites from garbage. "Clean Chusovaya Russia" is an environmental, local history project aimed at protection of cultural and natural heritage of the Chusovaya River from pollution and popularization of domestic eco-tourism.

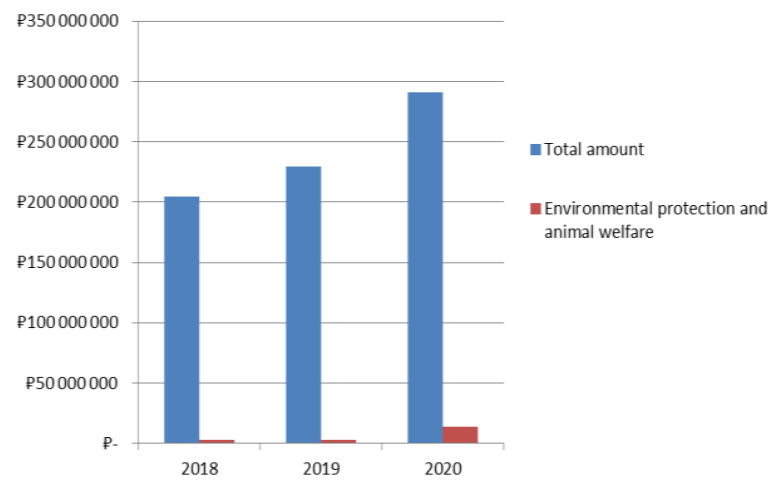

Figure 1 The amount of funds from the total funds for environmental protection and animal welfare in the Sverdlovsk region.

\section{AUTHORS' CONTRIBUTIONS}

As we can see from the table, funds are allocated for nature conservation and animal protection in insufficient quantities compared to the total amount of funds. But it should also be noted that the number of grants received by socially oriented non-profit organizations is growing year by year. Against the background of the ongoing Covid-19 pandemic, the number of funds received for environmental protection and conservation from the Presidential Grants Fund has increased significantly. Thus, we can conclude that the Russian government has revised its priorities and has begun to pay special attention to the environment. Consequently, this leads to an improvement in the quality of life of the population, reducing the outflow of residents, due to the unfavorable environmental situation in the Sverdlovsk region. Thus, the activities of socially oriented non-profit organizations contribute to nature conservation and animal protection, executing the supported projects.

\section{REFERENCES}

[1] A.N. Khorin, Yu.M. Potanina, A.V. Brovkin, Sector Non-profit Organizations in the
Management of Socio-Economic Systems. Journal of Legal. In: Ethical and Regulatory Issues, 20(1) (2017).

[2] Social Sustainability Concepts and Benchmarks, https://www.europarl.europa.eu/RegData/etudes/S TUD/2020/648782/IPOL_STU(2020)648782_EN. pdf

[3] Federal Statistical Service https://www.fedstat.ru/indicator/60324

[4] E. Dvoryadkina, D. Prostova, A. Eliseeva, Services of non-profit organisations in sustainable development and economic security of rural areas. In: E3S Web of Conferences, 254 (2021) 10017.

[5] P. Jepson, Governance and accountability of environmental NGOs. In: Environ Sci Policy, 8 (2005) pp. 515-524.

[6] R.L. Bryant, Born to Be Wild? Non-governmental Organisations, Politics and the Environment. In: Geogr Compass, 3 (2009) pp. 1540-1558.

[7] P. Larsen, The good, the ugly and the dirty harry's of conservation: Rethinking the anthropology of conservation NGOs. Conserv Soc., 14 (2016) pp. 21-33, DOI: https://doi.org/10.4103/09724923.182800

[8] P. West, Conservation is Our Government Now: The Politics of Ecology in Papua New Guinea. Durham: Duke University Press (2006).

[9] M. Cooper, Environmental Rhetoric in the Age of Hegemonic Politics: Earth First and the Nature Conservancy. In: Herndl C, Brown S, editors. Green Culture: Environmental Rhetoric in Contemporary America. Madison, WI: University of Wisconsin Press, pp. 236-260 (1996).

[10] C. Rootes, Facing south? British environmental movement organisations and the challenge of globalisation. Env Polit, 15 (2006) pp. 768-786.

[11] E.B. Dvoryadkina, D.M. Prostova, Nonprofit organisations in the regional economy: A theoretical approach to the research. In: Journal of New Economy, 20(4) (2019) pp. 47-69. DOI: https://doi.org/10.29141/2073-1019-2019-20-4-3 